\title{
Numerical hydrological and hydraulic simulation of the effects of a possible flood wave as part of a risk analysis and risk management at the Suggadinbach
}

\author{
G. Jaeger ${ }^{1} \&$ M. Moser ${ }^{2}$ \\ ${ }^{1}$ Technical Service for Torrent and Avalanche Control, \\ Department of Bregenz, Austria \\ ${ }^{2}$ Technical Service for Torrent and Avalanche Control, \\ Department of Lungau, Austria
}

\begin{abstract}
The Maesstobel bears high risks due to possible rockslides in the upper reach. Such a rock slide could result in a debris jam in the receiving stream 'Suggadinbach' caused by tumbling rock and debris flows of approximately 800,000 cubic metres. According to experts, dam failure and a consecutive flood wave would follow. The flood wave would then directly hit the town of St.Gallenkirch. In response to this scenario, a project has been designed which assesses the hazard potential and the effects of a possible flood wave on the residential area of St. Gallenkirch. Corresponding to the latest technical standards, laser scan data was used in the project to set up a digital terrain model. A detailed geological scan served as another basis. The hydrologic calculations were carried out with the aid of the HEC-HMS model. So as to know the extent to which dam failure would flood residential areas, various scenarios were assumed in hydraulic calculations and analyses. In order to increase accuracy and test plausibility, the simulation section was split into three sub sectors according to topographic and hydraulic aspects. In sector 1, debris flow in the Maesstobel was simulated (2D), involving its flow into the receiving river and the possible maximum height of retained debris and water. Sector 2 dealt with the scenario of dam failure, and it contains different variants of dam failure and the consecutive flood wave. In the third sector, there is the debris cone and the residential area of St.Gallenkirch. For this section, the worst case scenario was simulated (2D). Moreover, the threatened areas on the debris cone were defined. On the basis of these findings and results, a bundle of measures were taken as part of a risk management; also, a monitoring and early warning system was installed. Moreover, a new technical construction project, which contains three debrissorting dams, was carried out.
\end{abstract}

Keywords: debris flow, hydraulics and hydrology, flood risk, simulation. 


\section{Introduction}

Debris flows are significant natural hazards in mountainous regions. They endanger the lives of people and cause remarkable damage, due to their high velocity, their large proportions and frequent recurrence. The aim of the Forest Technical Service of Torrent and Avalanche Control in Austria is to carry out mitigation measures with a detailed risk analysis and risk management concept. Based on a field study in combination with modern simulation techniques and models, different scenarios were calculated.

\section{Problem}

The Maesstobel, having a catchment area of $0,42 \mathrm{~km}^{2}$, is situated in Vorarlberg/Austria and discharges into the river Suggadinbach [9].

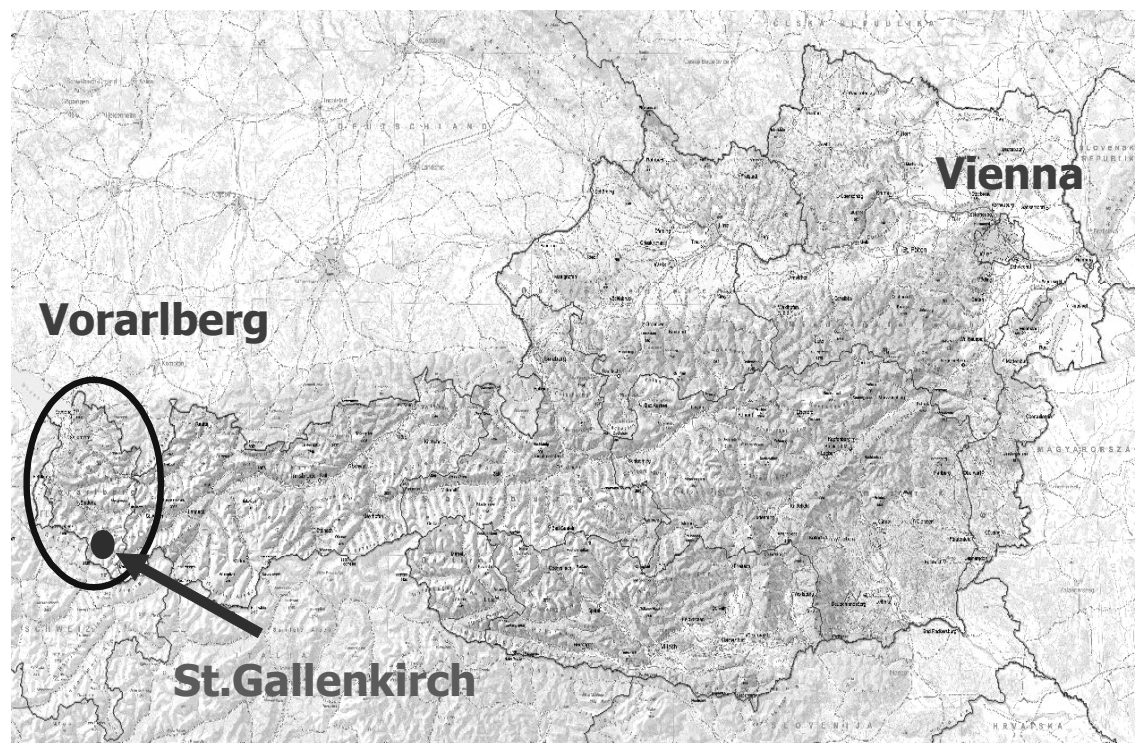

Figure 1: Location of the catchment area and characteristics [9].

In the Suggadinbach, there is the danger of a possible debris jam caused by tumbling rock and debris flows of approximately 800,000 cubic metres. According to experts, dam failure and a consecutive flood wave would follow. The flood wave would then directly hit the town of St. Gallenkirch. The existing hazard map for the village of St. Gallenkirch shows big red hazard zones on the fan of the tribuatry 'Suggadinbach'. After the flood event of 22 August 2005, the protection concept had to be reconsidered. 


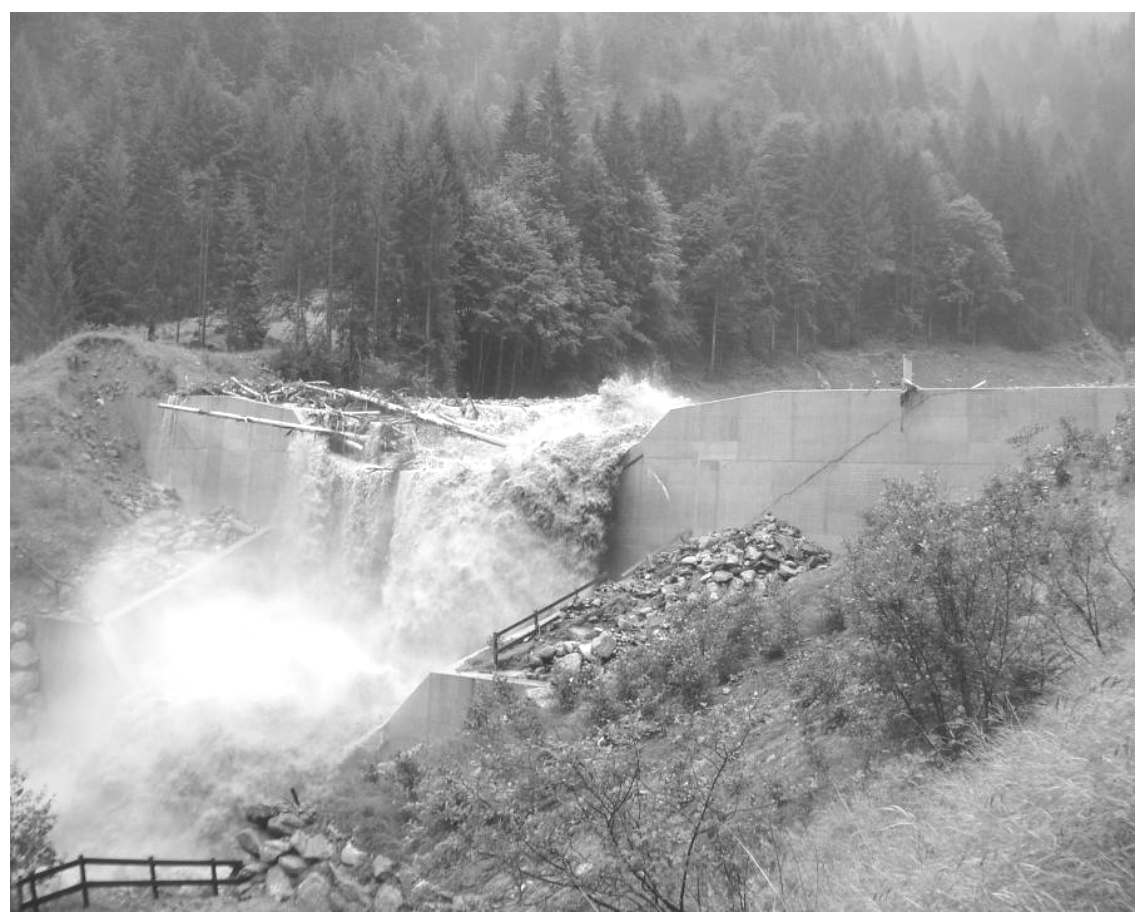

Figure 2: $\quad$ Debris sorting dam during the event in August 2005.

\section{The aim of the project}

The aim of the project was to develop a new protection concept, involving a monitoring and early warning system, based on a detailed risk assessment with modern simulation techniques. The objective of the project was as follows: on the basis of new insights and recordings of the Maesstobel catchment area, the hazard potential and the consequences of a subsequent flooding for the settlement area of St. Gallenkirch had to be assessed, and thereupon mitigation measures had to be derived to minimize the risk. The fundamental question was if the discharge peak, together with dam failure [1], would result in a higher hazard potential for the residential area at the deposition fan, or if the discharge peak would flatten in the course of the 2.2 kilometres of canyon reach - which would mean a slimmer hazard potential.

Corresponding to the latest technical standards, laser scan data was used in the project to set up a digital terrain model. Another basis was a detailed geological scan. The hydrologic calculations were carried out with the aid of the HEC-HMS model. As to how much a possible dam failure would flood residential areas, various scenarios were assumed in hydraulic calculations and analyses. So as to increase accuracy and test plausibility, the simulation section was split into three sub sectors according to topographic and hydraulic aspects. 
The results were used to derive a protection concept that combines active and passive mitigation measures.

\section{Method and protection strategy}

First of all, a detailed event documentation of the flood event in August 2005 was made. In the course of this, the triggering parameters were found. In addition to that, a geological in-depth study carried out by the Geognos BertleCompany provided the basis to estimate the volume of the rock slide [3]. Due to the new results, experts of different fields determined a cubature of $150,000 \mathrm{~m}^{3}$ of rocks and debris flows for the design event at the immediate confluence with the 'Suggadinbach'. This is the expected volume that would initiate the impounding of the Suggadinbach up to a height of $15 \mathrm{~m}$. Moreover, on the basis of a digital terrain model made up of laser scan data, a hydrological and hydraulic simulation was carried out. The model calibration could be made by simulating the event of August 2005. The hydrological calculation was carried out for the whole catchment area of the 'Suggadinbach' by the HEC-HMS model. Precipitation data according to Lorenz and Skoda served as the basis for this model [12].

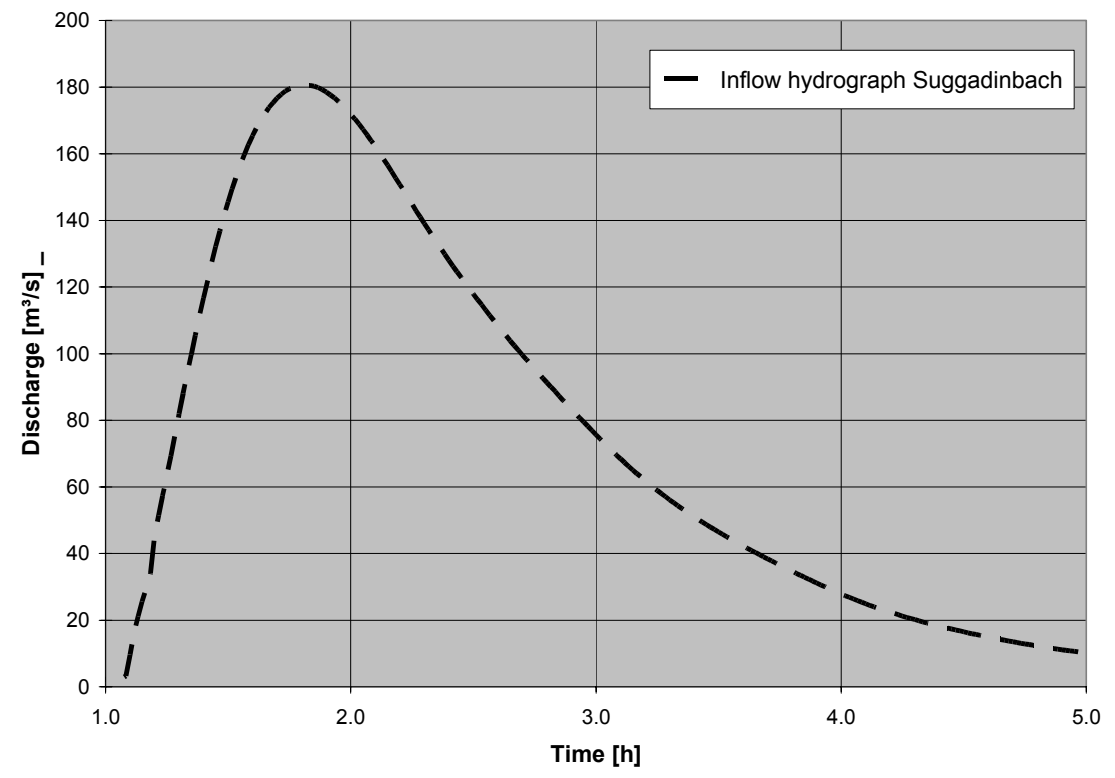

Figure 3: Discharge peak of the mainstream Suggadinbach.

The figures gained from the simulation allow for the following prediction in case of dam failure. It would take place at the discharge peak of $180 \mathrm{~m}^{3} / \mathrm{s}$. The breach would reach its peak after roughly 10 minutes and increase the discharge of the Suggadinbach from 180 to $380 \mathrm{~m}^{3} / \mathrm{s}$. The peak would be reached approximately 25 minutes after the beginning of the failure $[1,5,6]$. 
However, this scenario was calculated for pure water discharge. That is why a corresponding debris ratio was added to the scenario of a water hydrograph dam failure for further calculation of the flood wave, as the deposited bedload of the Maesstobel would subsequently be eroded by water and then carried on to lower reach or deposited at the fan. The discharge scenario assumed is a debris flow with $350.000 \mathrm{~m}^{3}$ of sediment. A discharge peak of $380 \mathrm{~m}^{3} / \mathrm{s}$ plus bedload would peak in approximately $760 \mathrm{~m}^{3} / \mathrm{s}$ [2].

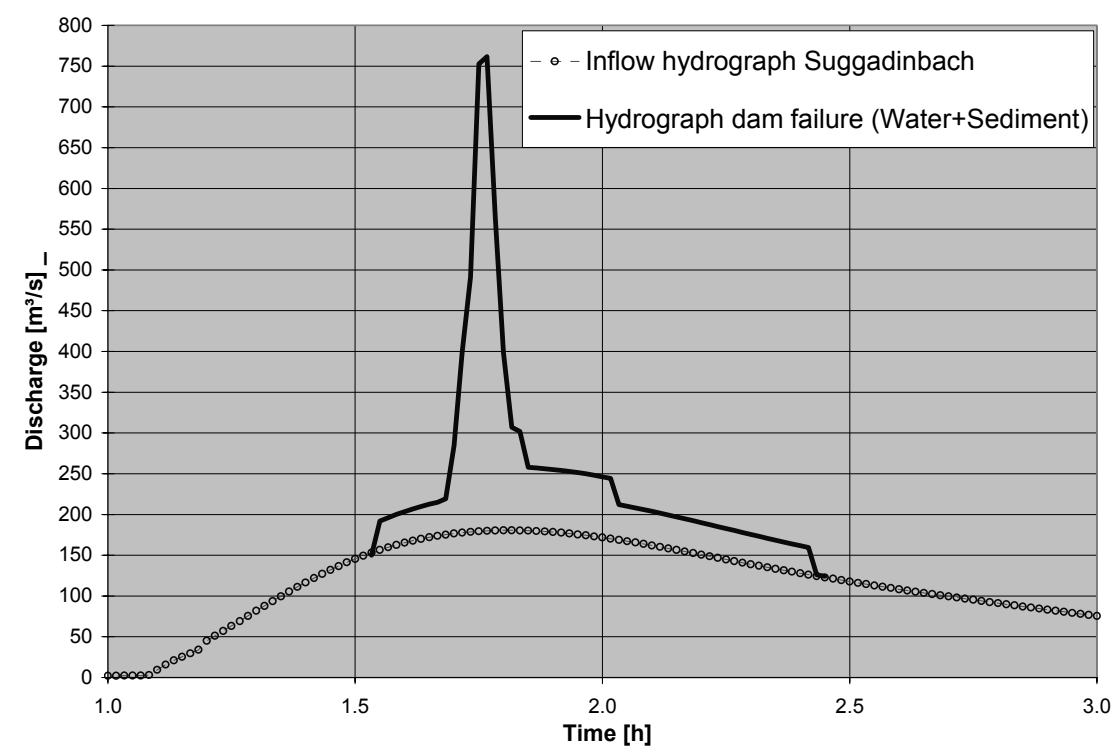

Figure 4: Hydrograph dam failure and inflow hydrograph Suggadinbach.

With the aid of calibrated models, the design event and different processes were simulated [15]. For that, the simulation area was split into three sectors. In sector 1, debris flow in the Maesstobel was simulated (FLO-2D) [7], involving its flow into the receiving river and the possible maximum height of retained debris and water. Sector 2 dealt with the scenario of dam failure (HEC-RAS), and it contained different variants of dam failure and the consecutive flood wave $[2,5]$. In the third sector, there is the debris cone and the residential area of St.Gallenkirch. For this section, the worst case scenario was simulated [7].

\section{Results and mitigation measures}

The threatened areas on the debris cone and the process characteristic in the middle reach were defined. On the basis of these findings and results, a bundle of active and passive measures were worked out as part of a risk management concept $[10,11]$. 


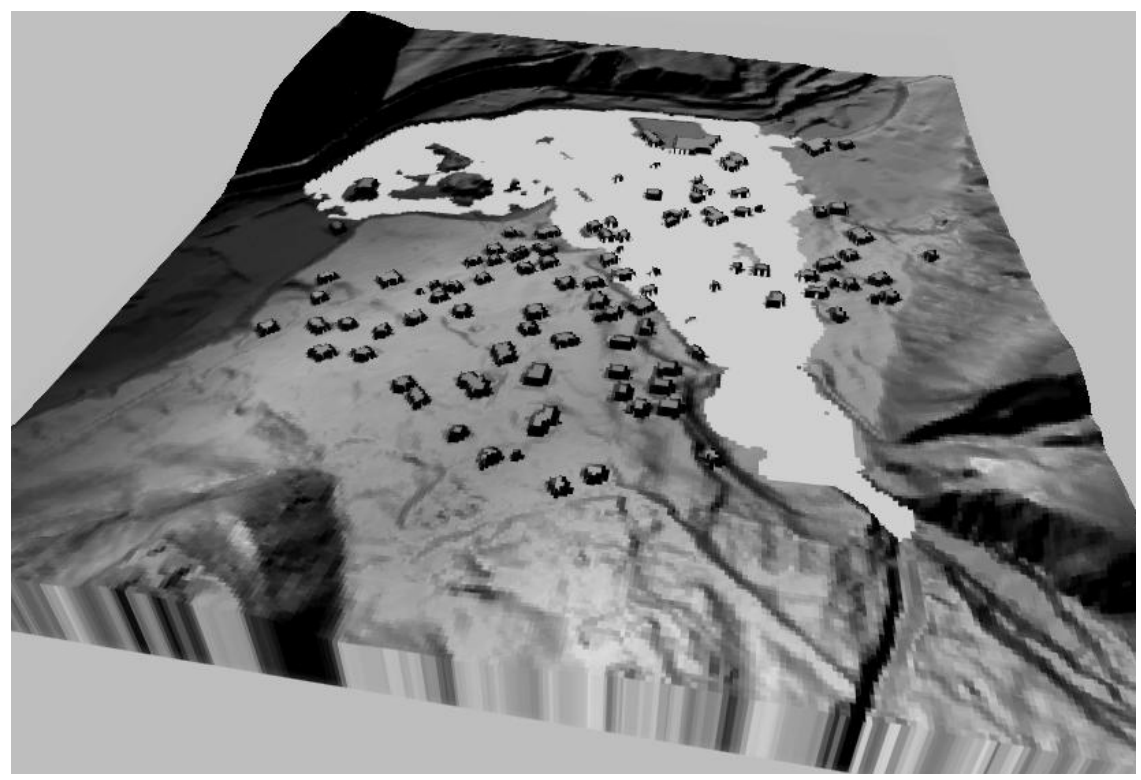

Figure 5: $\quad$ Threatened areas on the fan of St. Gallenkirch (white).

\subsection{Active mitigation measurements}

The bundle of active measures is concentrated in the middle reach and close to the fan of the village of St.Gallenkirch. In addition to the existing measures, three debris-sorting dams with a new technical construction for bedload sorting are planned [8]. These mitigation measures are the most effective protection against debris flows and sediment transport with a reduction of the high energy level to a lower level under particular energy change and bedload storage in the storage basins [4].

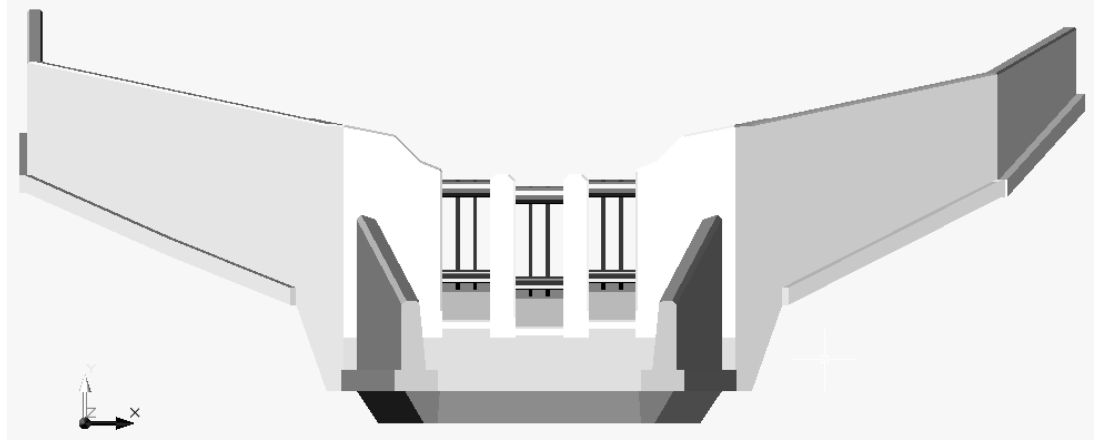

Figure 6: $\quad$ Example of a debris sorting dam [8,9]. 


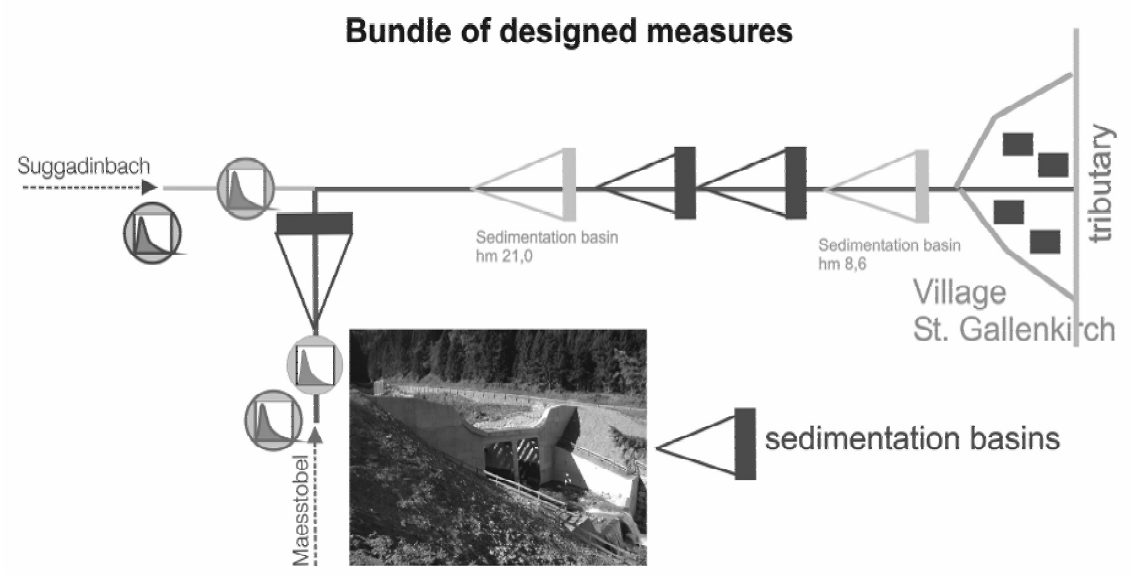

Figure 7: Existing and planned active mitigation measures in the middle reach.

\subsection{Passive measurements}

In addition to active measurement, passive mitigation measures such as a monitoring system were installed. The monitoring system is situated in the upper reach of the Maesstobel. In order to monitor movements of the starting zone, seven rope extensometers can register the changes. In addition to these, two inclinometers detect any changes within the loose rock area. The data is transmitted via radio. Within the falling area, 2 geophones register any ground vibration in order to trigger a just in time alarm that controls a traffic light which closes the nearby road. This monitoring system is technically improved in order to provide information to local authorities if a debris flow occurs [14].

\section{Conclusion}

The forest technical service of Austria carries out a bundle of measures including active and passive measurements for the protection of the villages and their residents. Up to now, the aim of the monitoring system has been to increase the knowledge of debris flow triggering conditions for an event warning system and to provide an alarm in case a debris flow should occur [13].

From the stored data the triggering values for the release of debris flows can be derived. In addition to that, better knowledge of the debris flow phenomena and the designing of adequate technical constructions can be achieved with the stored data sets. In the future - in light of a changing climate - the behaviour of the catchment area may change, and based on the stored data and new simulation techniques the protection concept will have to be adopted. 


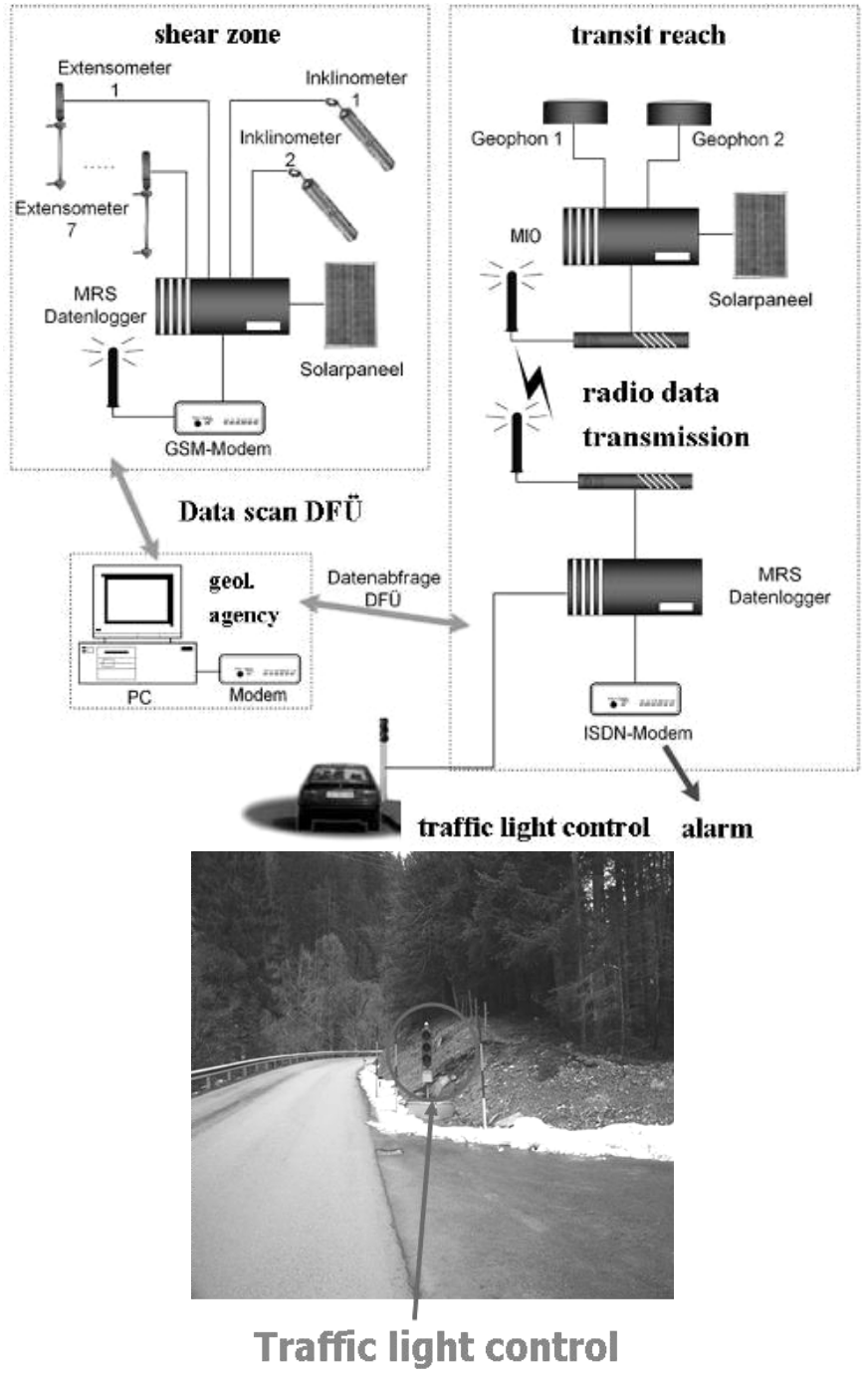

Figure 8: $\quad$ Information/monitoring system with warning traffic light [14].

\section{References}

[1] Beffa, C. (2001): Diagramme zur Bestimmung der flächigen Ausbreitung von Breschenabflüssen, In: Wasser, Energie, Luft, Heft $3 / 4$

[2] Beffa, C. (2002): Integration ein- und zweidimensionaler Modell zur hydrodynamischen Simulation von Gewässersystemen, Int. Symposium "Moderne Methoden und Konzepte im Wasserbau"; 7.-9. Oktober2002, ETH Zürich 
[3] Geognos Bertle (2004): Felsgleitung Maesstobel - geologischgeomorphologisch-hangtektonische Detailuntersuchung; Jahresbericht 2004

[4] Fiebiger, G. (1986): Management on torrent control by functional check dams, in: Mitteilungen der forstl. Bundesversuchsanstalt Wien, Vol. 159, $325-332$

[5] Frank, J. (1951): Betrachtungen über den Ausfluss beim Bruch von Stauwänden; In: Schweizerische Bauzeitung, 69 Jg., Juli 1951, Seite 401 406

[6] Hampel, R. (1960): Bruchversuch an einer Bogensperre der Wildbachverbauung; In. Österreichische Wasserwirtschaft, Heft 8/9, Jahrgang 12

[7] FLO-2d, 2-Dimensional Flood Routine Model Manual. Version 2006; Flo-2D Software Inc.

[8] Forsttechnischer Dienst Für Wildbach- Und Lawinenverbauung Gebietsbauleitung Bludenz (WLV 2000): Suggadinbach, Verbauungsprojekt 2000, Technischer Bericht und diverse Unterlagen

[9] Forsttechnischer Dienst Für Wildbach- Und Lawinenverbauung Gebietsbauleitung Bludenz (WLV 2002): Maesstobel, Bauprogramm für Einzelbaumaßnahmen 2003, Technischer Bericht und diverse Unterlagen

[10] Huebl, J., Moser, M. (2004): Risikomanagement Lattenbach: Generelle Planung von Schutzmaßnahmen, IAN Report 95 (2), Universität für Bodenkultur Wien, unveröffentlicht

[11] Huebl, J., Fiebiger, G. (2005): Debris-flow mitigation measures (Chapter 18), Debris flow Hazards and Related Phenomena, ed. Jakob, M. \& Hungr, O., Springer Verlag; Berlin, Heidelberg, New York, ISBN 3540-20726-0, pp. 445-487

[12] Jaeger, G., Moser, M. (2006): Numerische hydrologische und hydraulische Simulation am Beispiel Maesstobel und Suggadinbach; In: Bilanzveranstaltung der Wildbach- und Lawinenverbauung zum Fachschwerpunkt - Wildbachtransportprozesse, unveröffentlicht

[13] Jaeger, G., Moser, M., Huebl, J. (2005): Risk analysis and risk management Maesstobel, General Assembly, European Geosciences Union; Vienna, 24-29. April 2005, Poster

[14] Schmidt, R. (2002): Warnsysteme in Wildbacheinzugsgebieten; Wildbach- und Lawinenverbauung Vorarlberg, 6900 Bregenz, Rheinstrasse 32/4

[15] Steinwendtner, H. (2002): Einsatzmöglichkeiten von Numerischen Modellen im Zuge der Maßnahmenplanung in geschiebeführenden und murfähigen Wildbächen; unveröffentlicht. 